\title{
МИСТЕЦТВОЗНАВСТВО
}

DOI: https://doi.org/10.32839/2304-5809/2019-2-66-89

УДК 7.03;7:001.12

Филиппова О.Н.
Ассоциация искусствоведов (г. Москва)

М.Ю. ЛЕРМОНТОВ - ХУДОЖНИК И ПОЭТ (1814-1841 ГГ.)

Аннотация. В начале XIX века почти в каждой культурной дворянской семье хранился семейный альбом, который знакомые обязаны были заполнять стихами и рисунками. Историко-художественная ценность этих альбомов, как правило, невелика. Правда, подчас здесь встречаются вещи, отмеченные подлинным талантом и незаурядным мастерством, как, например, бытовые зарисовки Я.П. де Бальмена (1813-1845), сюита превосходных портретов Э.А. Дмитриева-Мамонова (1824-1883), замечательные альбомы П.И. Челищева (1804-1859), полные бытовых сценок и карикатур. Венцом этого дилетантского занятия живописью является творчество Г.Г. Гагарина (1810-1893), акварели и картины, которого, давно уже по праву занимают почетное место среди эскизов и полотен художников-профессионалов в наших музеях. Занимались живописью и многие выдающиеся писатели прошлого (А.С. Пушкин, М.Ю. Лермонтов, Т.Г. Шевченко, В.В. Маяковский и др.). Картины и акварели М.Ю. Лермонтова имеют совершенно самостоятельное значение. Большинство его рисунков или набросков местностей, в которых побывал поэт, это именно рисунки "на случай» $[1$, с.56].

Ключевые слова: М.Ю. Лермонтов-художник, поэт, акварельные зарисовки, домашнее рисование, юнкерские тетради, рисунок сепией, отдельные листы, альбомы, карикатуры, автошарж, автолитография, автопортрет.

Filippova Olga

Association of Art Critics (Moscow)

\section{M.Y. LERMONTOV AS AN ARTIST AND POET (1814-1841)}

Summary. At the beginning of the XIX century, almost every cultural noble family kept a family album, which friends were required to fill with poems and drawings. The historical and artistic value of these albums is usually low. However, sometimes there are things that are marked by genuine talent and outstanding skill, such as, for example, household sketches by J.P. de Balmain (1813-1845), a Suite of excellent portraits by E.A. Dmitriev-Mamonov (1824-1883), wonderful albums by P.I. Chelishchev (1804-1859), full of everyday scenes and caricatures. The crown of this Amateur painting classes is the work of G.G. Gagarin (1810-1893), watercolors and paintings, which has long been rightfully occupy an honorable place among the sketches and paintings of professional artists in our museums. Engaged in painting and many outstanding writers of the past. Picturesque and graphic experiments are kept in the heritage of almost each of them. Some of these experiments were small, random, were quite "amateur" character and did not deserve special attention from the historians of literature. These are drawings N.I. Gogol, who although attended drawing classes of the Academy of arts, but did not find not only the most elementary skill, but also a simple skill. These are the sketches and cartoons of I.S. Turgenev or L.N. Tolstoy, conclusively prove the lack of and that and the other the predilection for the fine arts. Other writers drew a lot and willingly, displaying not only an innate talent, but also outstanding technical skills; such as V.A. Zhukovsky, J.P. Polonsky. However, the pictorial and graphic experiences of these writers, as a rule, have nothing to do with their literary work. They give sometimes useful material for a biographer, but for a literary historian they are of little importance. The most interesting is the picturesque and graphic heritage of those writers who have been closely and organically engaged in painting and graphics were associated with their creativity in the field of artistic words, such as A.S. Pushkin, M.Y. Lermontov, T.G. Shevchenko and V.V. Mayakovsky. Paintings and watercolors of M.Y. Lermontov have a completely independent value. Most of his drawings or sketches of the areas in which the poet visited-these are drawings «in case».

Keywords: M.Y. Lermontov as an artist, poet, watercolor sketches, home drawing, cadet notebook, Sepia pattern, separate sheet, albums, caricatures, autoshare, autolithography, selfportrait.

$\Pi$ остановка проблемы. Творческая индивидуальность Михаила Юрьевича Лермонтова не ограничивается поэтическим гением. Интерес к изобразительному искусству, проявившись очень рано, как бы сопутствует его литературным замыслам и образам. Несомненно, что М.Ю. Лермонтову было свойственно именно живописное видение мира. Его поэтической системе присущи такие эпитеты и сравнения, которые помогают создать впечатление живописной картины с определенной красочной гаммой и светотеневыми контрастами. В своих литературных произведениях он нередко при- бегает к законам композиции пространственных искусств. Эта особенность ярче всего сказывается в тех случаях, когда М.Ю. Лермонтов вводит в повествование пейзаж.

Анализ последних исследований и публикаций. Так сложилось, что среди великих русских писателей М.Ю. Лермонтов долгое время оставался наименее изученным. В 1906 году А.А. Блок говорил о загадках его поэзии, о его «нищенской» биографии и призывал искать «лермонтовский клад» [3, с. 3]. В то время к серьезному изучению живописного наследия М.Ю. Лермонтова исследователи по-существу не приступали. 
Хотя о художественных занятиях поэта было известно давно и круг знакомых М.Ю. Лермонтова видел его работы, а некоторые из них воспроизводились в изданиях его сочинений, связь между поэтическим даром и художественными склонностями М.Ю. Лермонтова не привлекала внимания. М.Ю. Лермонтов - поэт воспринимался сам по себе, картины же и рисунки представлялись чемто отдельным. Между тем, глубокая, хотя подчас и скрытая связь дарования М.Ю. Лермонтовапоэта и М.Ю. Лермонтова-художника все же существует. Впервые на это было обращено внимание только в предреволюционные годы, в последнем пятом томе первого академического издания сочинений М.Ю. Лермонтова [5]. В период с начала 1930-х годов по 1970-е годы положение решительно переменилось.

М.Ю. Лермонтовым стали заниматься упорно, изучали его разносторонне. Определилось его место и роль в русской и мировой литературе. И все же «лермонтовский клад» до сих пор до конца не раскрыт [3, с. 3]. Цель данной публикации - это раскрыть живописное и графическое наследие М.Ю. Лермонтова и показать, как оно было неразрывно связано с его поэтическим творчеством.

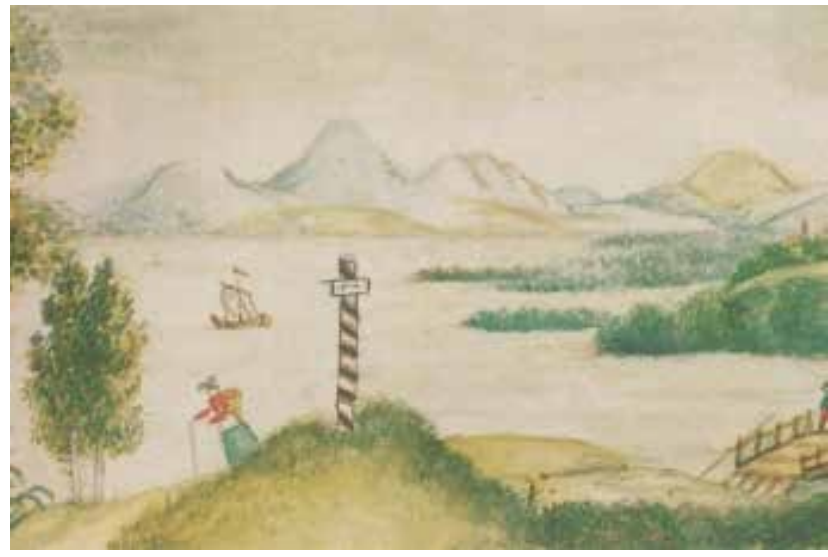

Илл. 1. М.Ю. Лермонтов. «Пейзаж с озером». 1825 г. Бумага, акварель, 9,2 × 15,5 см // Ф.429. Лермонтов М.Ю. Д.41. Л.65. (Акварель из альбома М.А. Шан-Гирей) // Российская национальная библиотека (Санкт-Петербург)

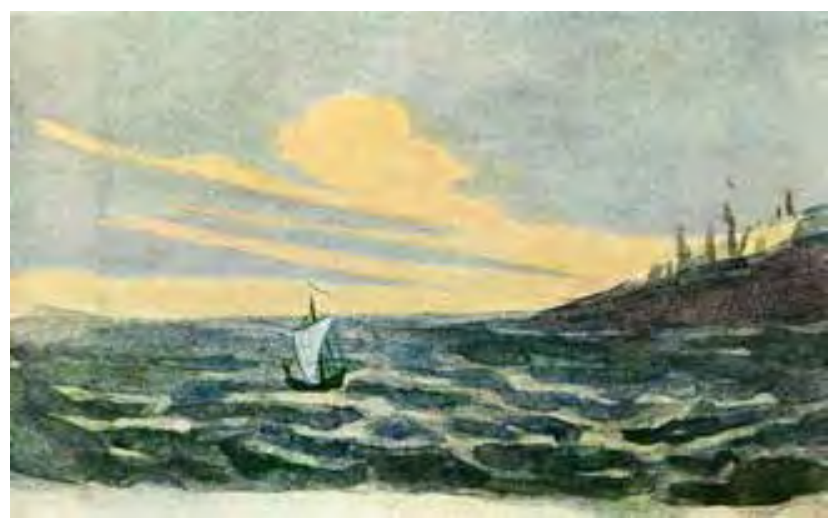

Илл. 2. М.Ю. Лермонтов. «Морской вид с парусной лодкой». 1828-1831 гг. Бумага, акварель, 9,2 × 15,5 см // Ф.429. Лермонтов М.Ю. Д.41. Л.24. (Акварель из альбома

М.А. Шан-Гирей) // Российская национальная библиотека (Санкт-Петербург)
Любовь к рисованию проявилась у М.Ю. Лермонтова очень рано. По рассказам российского писателя С.А. Раевского (1808-1876), пол в детской будущего поэта в Тарханах был покрыт сукном, и величайшим удовольствием ребенка было ползать по нему и чертить мелом. Любопытно, что на самом раннем портрете, очевидно, заказанном бабушкой неизвестным художником, М.Ю. Лермонтов изображен в возрасте 4-5 лет с мелком в правой руке. Несколько позднее М.Ю. Лермонтов начинает лепить из воска, выполняя, по свидетельствам современников, сложные композиции на исторические темы. Первым учителем поэта стал малоизвестный художник А.С. Солоницкий. Будучи выпускником Императорской Академии художеств, он преподавал тем же методом, которым учился сам. В основе его было копирование произведений известных художников. Сохранились ученические программные копии М.Ю. Лермонтова: с картины А.П. Лосенко «Андрей Первозванный», «Младенец, тянущийся к матери» и «Мадонна с младенцем» [2, с. 7]. От копирования переходили к рисованию с «бюстов», гипсовых слепков античных скульптур [2, с. 7]. Наиболее ранние акварели поэта, выполненные им совершенно самостоятельно, без помощи учителя, относятся ко времени путешествия на Кавказ, куда его возила бабушка Елизавета Алексеевна Арсеньева (1773-1845). Она надеялась поправить здоровье внука целебными водами и чистым горным воздухом Горячеводска, где было имение их близких родственников. Горы Кавказа, его природа и люди произвели на одиннадцатилетнего мальчика неизгладимое впечатление, которое отразилось и в поэзии, и в его акварельных зарисовках. Одна из ранних акварелей - это «Пейзаж с озером» (1825) [2, с. 8] (илл. 1).

Этот набросок, выполненный на желтоватой тонированной бумаге в золотисто-голубой цветовой гамме, еще по-детски наивен, но в нем уже чувствуется умение автора передать свежесть новых впечатлений. К раннему периоду относится также его «Морской вид с парусной лодкой» [2, с. 8] (илл. 2).

Позднее мотив прозвучит в поэтическом творчестве М.Ю. Лермонтова, в том числе в широко известном стихотворении 1832 года «Белеет парус одинокий...» [2, с. 8]. Романтическим мировосприятием отмечен и «Пейзаж с двумя березами», выполненный, очевидно, в Тарханах: здесь чувствуется рука начинающего, но способного рисовальщика [2, с. 8]. «Чета берез» позднее будет упомянута в стихотворении 1841 года "Родина» [2, с. 8]. "Домашнее рисование» обычно имело продолжение в любом учебном заведении [2, с. 8]. Для М.Ю. Лермонтова это был Московский университетский пансион, где рисование входило в число обязательных предметов. Если подобное обучение и не давало достаточно профессионального уровня, то, во всяком случае, у воспитанников появлялось умение с легкостью делать беглые наброски: они, что называется, «набивали руку» [2, с. 8].

Именно этим отличаются рисунки М.Ю. Лермонтова в так называемых «юнкерских тетрадях», относящихся к раннему петербургскому периоду, когда он поступил в Школу гвардейских подпрапорщиков и кавалерийских юнкеров 
[2, с. 8]. Скучая на занятиях, поэт набрасывал пером или карандашом то портреты товарищей, то сценки из жизни юнкеров. Подобные наброски были интересны окружающим, они в них легко угадывали себя и товарищей по полку. На одном из рисунков представлен урок верховой езды в манеже. На первом плане спиной к зрителю изображен военный с хлыстом в руке: хотя он показан со спины, современники узнавали в нем әскадронного командира А.С. Стунеева. В юнкере, гарцующем на коне у окна манежа, видели приятеля М.Ю. Лермонтова - В.А. Вонлярлярского, а в персонажах, изображенных возле барьера, - Н.И. Поливанова и унтер-офицера Жолмира. Особенно выразителен набросок в 22-й тетради: здесь изображен молодой человек, задумчиво смотрящий в окно. Юношеский профиль, вписанный в прямоугольник оконного стекла, лаконично очерченный силуэт фригуры в наброшенной на плечи юнкерской шинели все пронизано ощущением томительного одиночества. Воспитанники Школы нередко вспоминали о родном доме, друзьях и близких, оставленных за стенами учебного заведения.

Однако, долго предаваться воспоминаниям они не могли: постоянные учения, занятия в манеже, маневры заполняли все дни напролет. Отголосок этого мы находим в рисунке сепией «Маневры в Красном Селе» [2, с. 9] (илл. 3).

Здесь на дощатом мостике, перекинутом через проток, гарцуют на конях офицеры, в одном из которых юнкера узнавали генерала К.А. Шлиппенбаха. Своих полковых товарищей М.Ю. Лермонтов рисовал не только в юнкерских тетрадях, но и на отдельных листах, в альбомах. Акварель «Бивуак лейб-гвардии Гусарского полка под Красным Селом» (1835) изображает группу офицеров, расположившихся среди невысоких деревьев и кустарников [2, с. 9] (илл. 4).

Все представленные здесь лица хорошо были известны благодаря надписи на раме: это корнет князь Н.С. Вяземский, ротмистры Г. Витт, А.Г. Ломоносов и другие. Акварель представляет собой не только ценный документ, она свидетельствует о художественных предпочтениях поэта этого периода. Продуманная постановка отдельных групп офицеров, лица, имеющие черты портретного сходства, изображение лошадей в движении и сильном ракурсе - все это требовало определенных навыков. Карикатуры в юнкерских тетрадях хотя и составили М.Ю. Лермонтову известность в среде товарищей, однако далеко не всегда были безобидными. Страницы альбомов 1830-х годов были заполнены шаржированными зарисовками не только военных, но и представителей светского общества. Это батальные сюжеты, бытовые сценки и профили портретного характера, граничащие с карикатурой. Каждая из зарисовок связана с конкретной ситуацией, за каждой стоят реальные персонажи, известные в обществе, и реальные ситуации, характеризующие их отнюдь не лестно. Подобными беглыми набросками был заполнен и альбом A.M. Bepeщагиной (1810-1873), друга юности поэта. В альбоме изображено немало занятных лиц: штабофицер, затянутый в мундир, барышня в бальном платье, присевшая отдохнуть после быстрого танца, кавалер, склонившийся перед ней

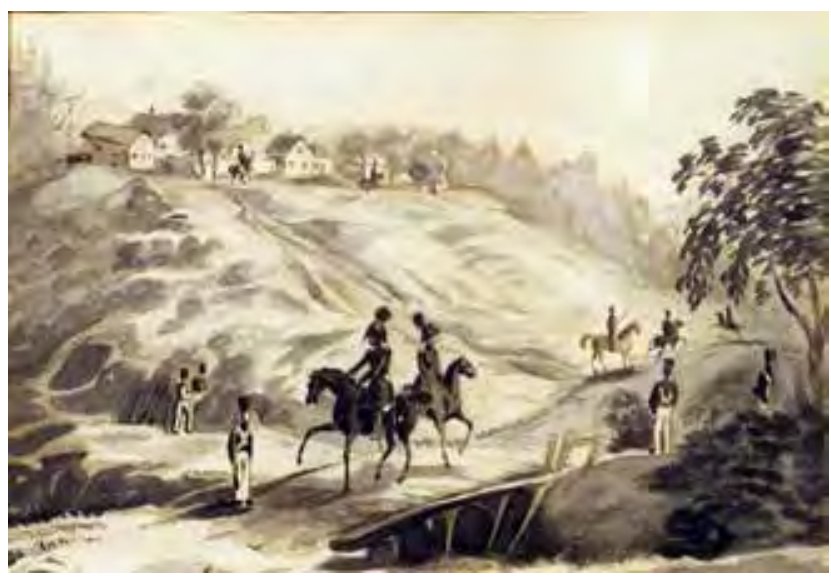

Илл. 3. М.Ю. Лермонтов. «Маневры в Красном Селе». 1833-1834 гг. Бумага, сепия, 16,4 × 21,0 см // Произведение было утрачено в 1941 году; воспроизводится с сохранившегося негатива

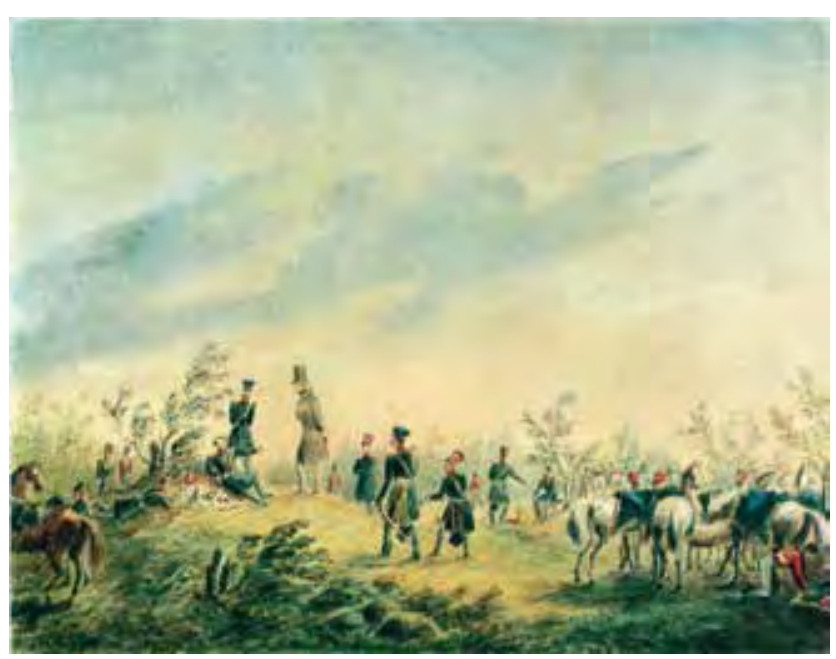

Илл. 4. М.Ю. Лермонтов. «Бивуак лейб-гвардии Гусарского полка под Красным Селом». 1835 г. Бумага, акварель, 16,8 × 21,4 см // Российская государственная библиотека (Москва)

в почтительном поклоне, сановный чиновник в длинном плаще. Нередко зарисовки дополнялись имитированными репликами персонажей, в этом случае их сатирическая направленность усиливалась. На одном из альбомных листов встречаем молодого офицера в вицмундире, с кавалерийской саблей и шляпой, украшенной плюмажем. Офицер показан со спины, в нем исследователи склонны видеть автошарж поэта.

Легким шаржированием отмечен также рисунок, изображающий молодого человека во фрраке. Персонаж маленького роста, с вьющимися волосами и вздернутым носом: в нем усматривают сходство с композитором А.С. Даргомыжским (1813-1869). Молодой человек склонился перед сидящей в кресле женщиной, предположительно, Е.А. Сушковой (1812-1868). Образ кареглазой брюнетки с высокой прической, в бальном платье не раз появляется в зарисовках и стихотворениях поэта. Другой альбом, также принадлежавший A.M. Верещагиной, хранит стихи и рисунки М.Ю. Лермонтова 1830-1836 годов, среди них преобладают акварели. На одной из них изображена Варвара Александровна Лопухина (1815-1851) (илл. 5). 


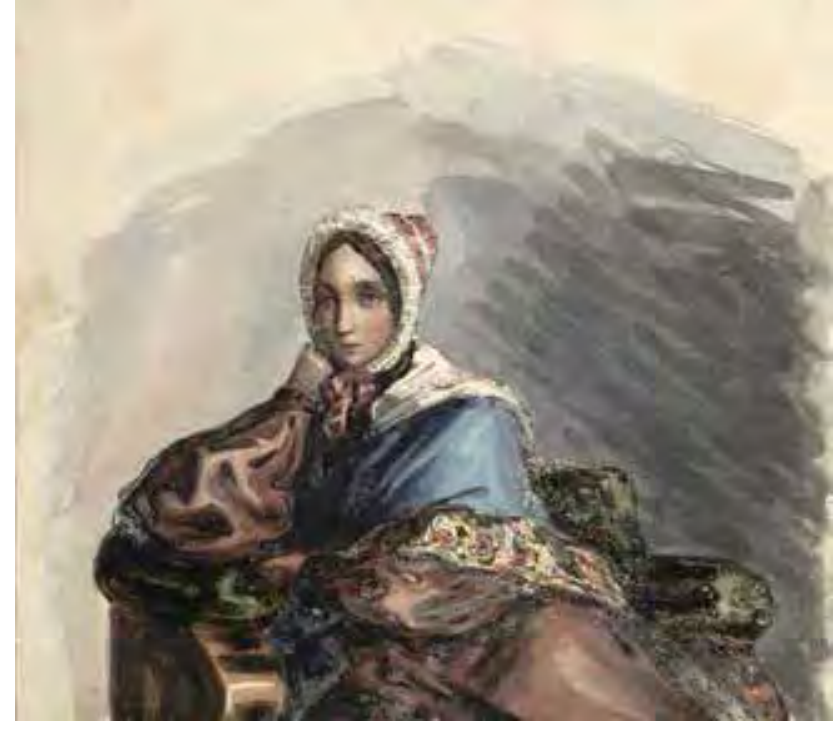

Илл. 5. М.Ю. Лермонтов. «Вера - героиня романа «Княгиня Лиговская». 1835-1836 гг.

Бумага, акварель, 14,0 × 15,0 cм // Пушкинский дом (ИРЛИ РАН, Санкт-Петербург)

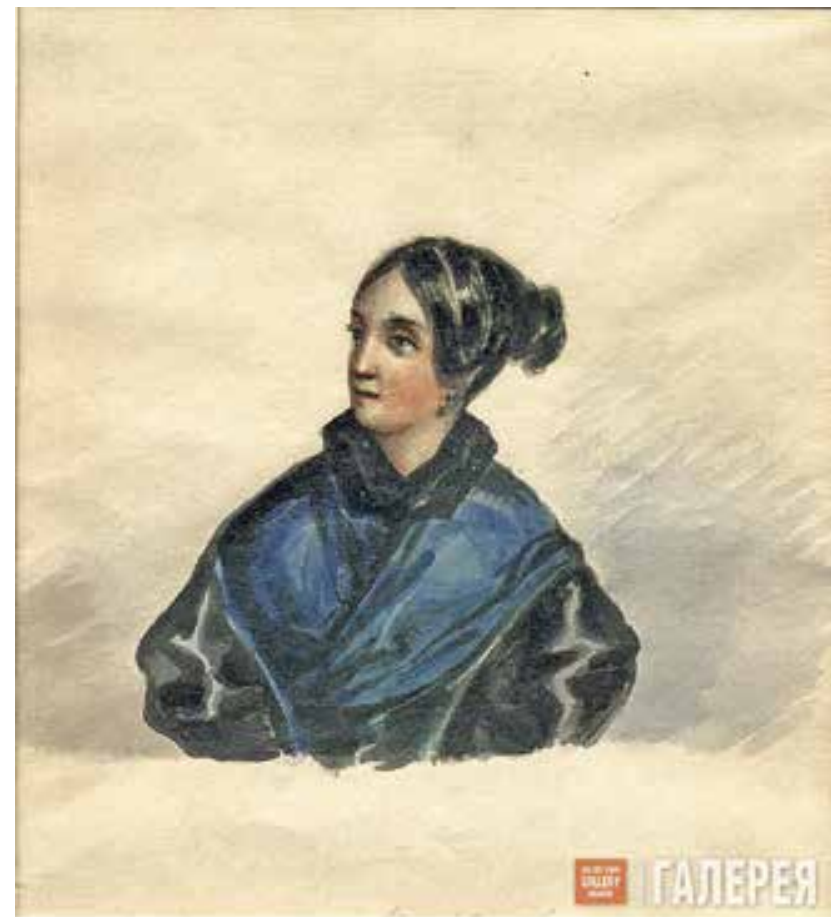

Илл. 6. М.Ю. Лермонтов. «Портрет В.А. Лопухиной». 1835-1838 (?).

Бумага, акварель, тушь (?), 19,7 × 16,2 см // Пушкинский дом (Литературный музей ИРЛИ РАН, Санкт-Петербург)

Они были знакомы еще с юности: в Москве, на Молчановке, дом бабушки М.Ю. Лермонтова располагался напротив дома Лопухиных. Поэт был дружен с братом Вареньки, знаком со всем ближайшим окружением, они вместе проводили лето в Середникове. Увлечение В.А. Лопухиной относится к последним годам учебы в Московском университете. Названная акварель относится к концу декабря 1835 года, когда, отправившись в Тарханы, М.Ю. Лермонтов остановился в Москве. Здесь он вновь встретил Вареньку, только теперь она была замужем за Н.Ф. Бахметьевым,

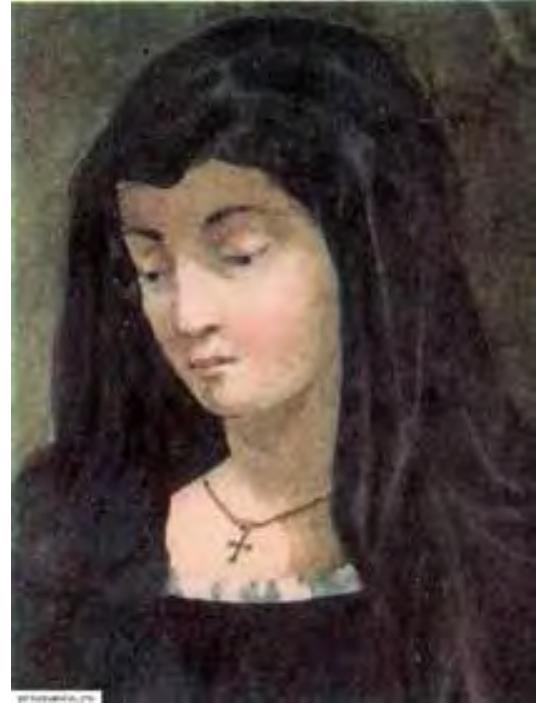

Илл. 7. М.Ю. Лермонтов. «Эмилия - героиня драмы М.Ю. Лермонтова «Испанцы"». 1830-1831 гг.

Бумага, акварель, белила, 14,3 × 11,3 cм (в свету), рама 15,8 × 12,9 см // Государственный Литературный музей (Москва)

человеком почти на двадцать лет старше ее. Поэт изобразил изящную молодую женщину в синем атласном капоте и блондовом чепце. Завернувшись в шаль и подперев голову рукой, она уютно устроилась в глубоком кресле.

Ее лицо с правильными чертами и огромными темными глазами несет печать грустных раздумий. Эта встреча и образ, который глубоко поразил поэта, были описаны им в незавершенном романе «Княгиня Лиговская», где В.А. Лопухина стала прототипом Веры Дмитриевны [2, с. 11]. Поэту принадлежит и другой погрудный портрет В.А. Лопухиной (илл. 6).

Это также акварель на тонированной желтоватой бумаге. Мы вновь видим лицо с огромными глазами, матовая бледность его подчеркнута темным цветом густых, стянутых на затылке, волос. Правильные черты в сочетании с аттической прической придают образу внутреннюю сдержанность. Портрет Вареньки, данный в стихотворении 1832 года «Она не гордой красотою», гармонирует с живописным изображением [2, с. 11]. Существует еще один портрет Варвары Александровны, выполненный М.Ю. Лермонтовым (илл. 7).

На нем она представлена в виде испанской монахини. Это один из самых обаятельных и тонких женских образов в художественном наследии поэта. Его создание относится ко времени работы над драмой: «Испанцы» (1830) и соответствует ремарке в третьем действии пьесы: «Эмилия входит бледная в черном платье, в черном покрывале и с крестиком на груди своей» [2, с. 12]. Печальному лицу молодой женщины М.Ю. Лермонтов сообщил черты В.А. Лопухиной. Потупленный взор больших черных глаз, скорбное выражение и матовая бледность придают образу особое драматическое звучание.

Судьба распорядилась, таким образом, что кроме Тархан, Москвы и Петербурга большую роль в жизни поэта сыграл Кавказ. Он был там ребенком, вместе с бабушкой. Затем, буду- 


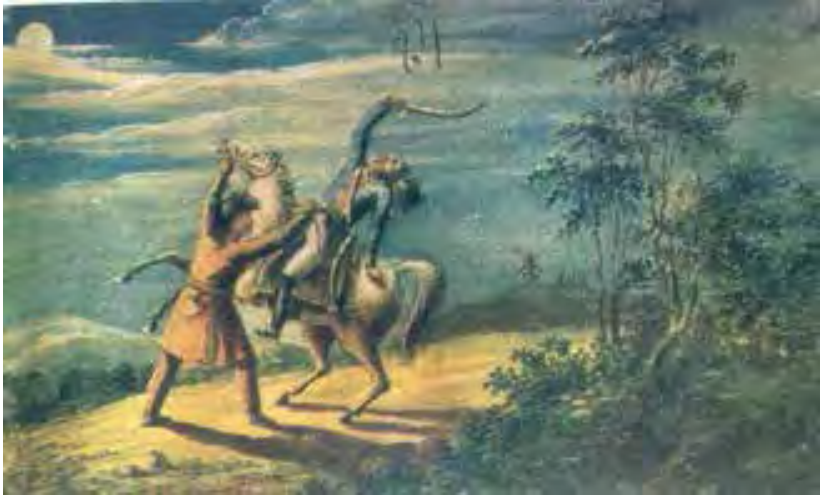

Илл. 8. М.Ю. Лермонтов. «Нападение». 1829 г. Бумага, акварель, 9,2 × 15,5 cм // Ф.429.

Лермонтов М.Ю. Д.41. Л.84. (Акварель из альбома М.А. Шан-Гирей) // Российская национальная библиотека (Санкт-Петербург)

чи молодым опальным офицером, должен был уехать в ссылку. Кавказ всегда производил на М.Ю. Лермонтова неизгладимое впечатление, а тема кавказской войны прошла через все его творчество. Еще в детстве он был покорен природой и самобытностью неведомого ему края. Bсе эти яркие впечатления отразились в стихах и рисунках юного поэта. На одном из них, «Нападении» 1829 года, изображен коварный черкес, останавливающий на скаку конного русского солдата и вонзающий ему в грудь кинжал [2, с. 12] (илл. 8)

Акварель, выполненная четырнадцатилетним автором, несмотря на наивный романтизм, удачно передает стремительность движений горца и создает впечатление внезапности нападения. Тема войны прозвучала и в рисунках начала 1830-х годов, и в экспрессивных иллюстрациях к «Кавказскому пленнику» и повести А.А. Бестужева-Марлинского «Аммалат-Бек» (1832) [2, с. 12]. Позднее, во время первой кавказской ссылки, куда М.Ю. Лермонтов был отправлен в 1837 году за стихотворение «Смерть поэта", эта тема получила дальнейшее развитие [2, с. 12$]$. Она отразилась в серии рисунков и живописных картин, передающих удивительную природу неведомого «дикого края» [2, с. 12]. Одним из удачных рисунков является «Мельница Волобуева» (1837) [2, с. 13] (илл. 9).

Несколькими динамичными мазками кисти намечен общий фон, на котором показана старая мельница, стоящая на холме над стремительным водным потоком. Сочетание коричневато-охристой туши с желтоватой тонированной бумагой помогает передать романтическое ощущение южной ночи. Рисунок сопровождается надписью, сделанной рукой М.Ю. Лермонтова: «21 Мая после прогулки на мельницу Волобуева» [2, с. 13]. В дороге поэт заболел, и после лечения в ставропольском госпитале его направили в Пятигорск. Он поселился в небольшом мазанковом домике. С подножия горы Машук открывался прекрасный вид на город. Именно отсюда и зарисовал его М.Ю. Лермонтов, сделав небольшой набросок. Позднее он написал большую живописную картину, на которой представлена панорама Пятигорска (илл. 10).

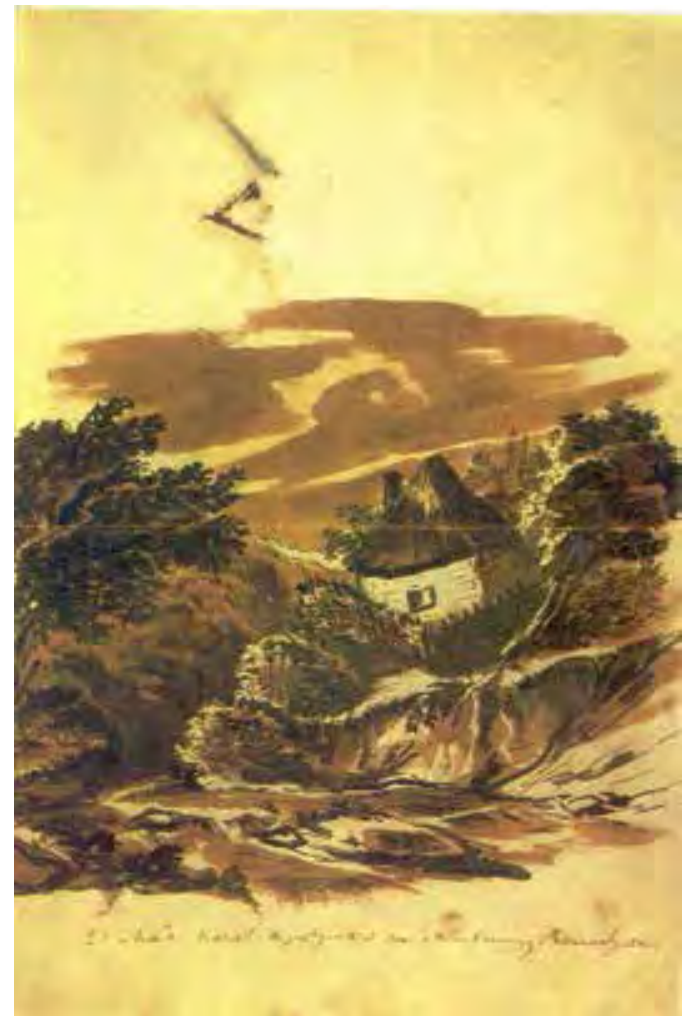

Илл. 9. М.Ю. Лермонтов. «Мельница Волобуева". 1837 г. Бумага, тушь, 33,2 × 22,0 см // Собрание

И.С. Зильберштейна (Музей изобразительных искусств имени А.С. Пушкина, Москва)

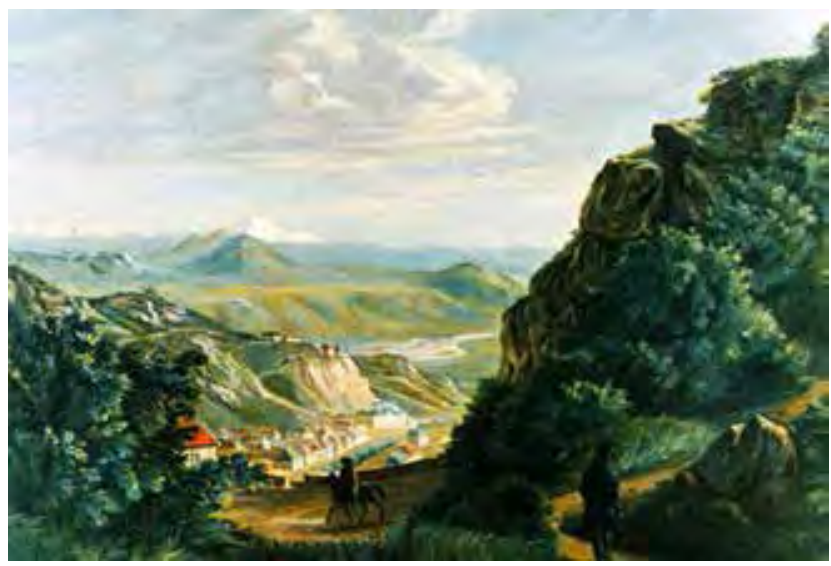

Илл. 10. М.Ю. Лермонтов. «Пятигорск».

1837-1838 гг. Картон, масло, 26,6 × 34,4 см // Государственный Литературный музей (Москва)

Здесь на первом плане изображена извилистая тропинка, ведущая по склону, поросшему невысоким кустарником. По ней, не торопясь, взбирается одинокий путник, который направляется к скалистому гроту, местной достопримечательности. Большой придорожный камень у правого нижнего края картины и зеленый кустарник слева, словно кулисы, приоткрывают вид на каменистую площадку. За ней, на пологих склонах горы раскинулся город с его небольшими выбеленными домиками и бульваром. Вдали видны долина реки Подкумок, горы Юца и Джуца, а на горизонте снежные вершины Эльбруса. Продуманная композиция следует строгим академическим правилам: мы видим 
четкое деление на пространственные планы, верное цветовое решение. Все это говорит о профессиональном подходе. Здесь сказались и уроки художника П.Е. Заболотского, и знание основ создания пейзажных композиций.

Это уже не дилетантские упражнения, а подлинно профрессиональное произведение, которое могло бы сделать честь любому выпускнику

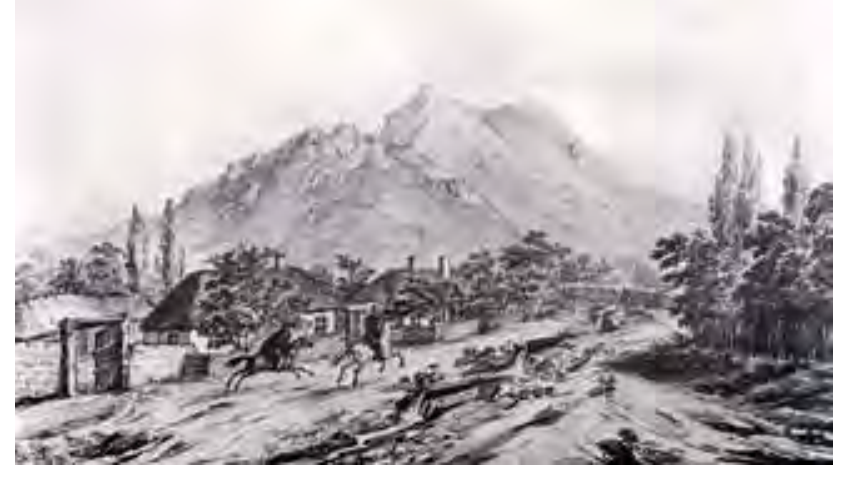

Илл. 11. М.Ю. Лермонтов. «Бештау близ Железноводска". 1837 г. Бумага, итальянский карандаш, 17,6 × 27,3 см // Государственный Литературный музей (Москва)

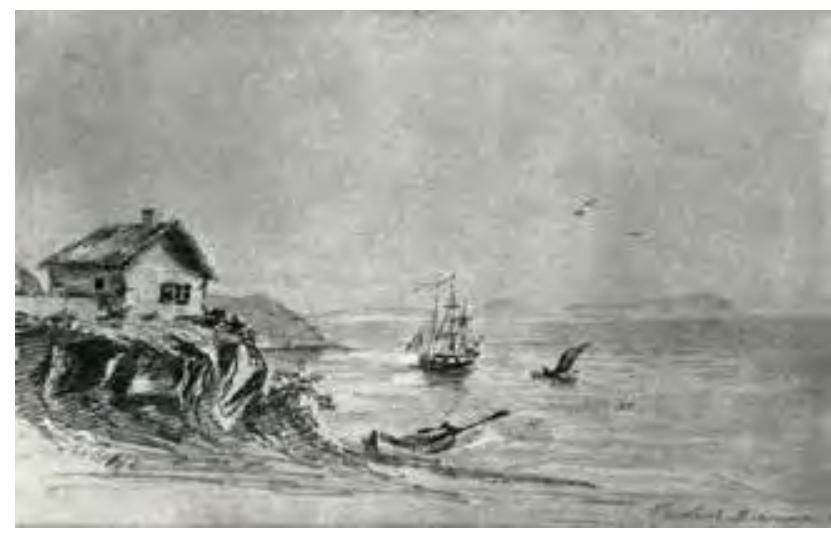

Илл. 12. М.Ю. Лермонтов. «Тамань». 1837 г. Бумага, карандаш, 20,7 × 30,5 см //

Пушкинский дом (Литературный музей ИРЛИ РАН, Санкт-Петербург)

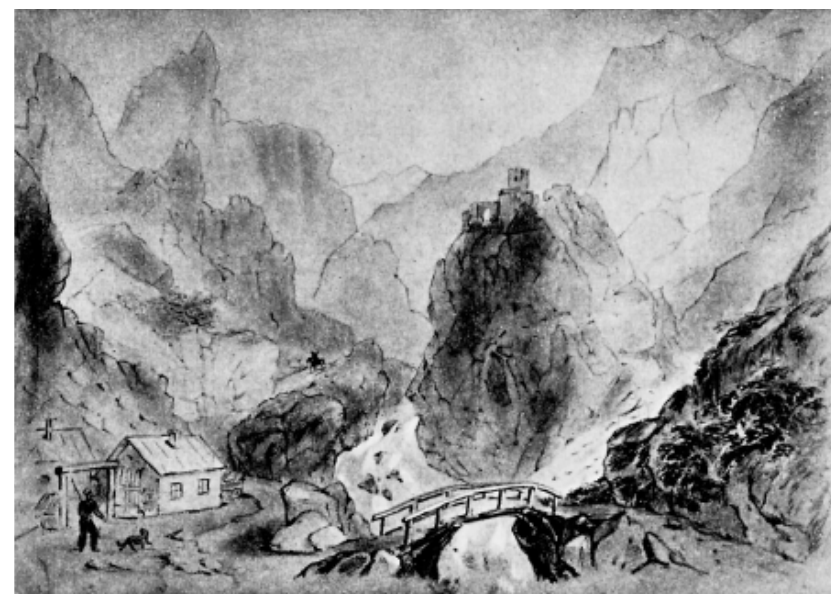

Илл. 13. М.Ю. Лермонтов. «Дарьял". 1837 г. (?). Бумага, графитный карандаш, $22,3 \times 31,3 \mathrm{~cm} \mathrm{//}$ Пушкинский дом (Литературный музей ИРЛИ РАН, Санкт-Петербург)
Академии художеств. Скорее всего, картина написана позже, чем сделан карандашный набросок: видимо, когда у М.Ю. Лермонтова появилась возможность спокойно предаться занятиям живописью. Передвигаясь на перекладных по почтовому тракту, не имея ни времени, ни условий для работы масляными красками, он вынужден был довольствоваться беглыми зарисовками небольшого формата. Русский писатель И.Л. Андроников считает, что «Пятигорск», как и другие живописные полотна, был написан М.Ю. Лермонтовым после его возвращения из ссылки в Петербург [2, с. 14]. С описанием Пятигорска были связаны строки и из «Героя нашего времени» (1837-1841) [2, с. 14]. Недалеко от Пятигорска находится Железноводск, также славящийся своими целебными источниками. Никто из "водяного общества" не миновал его, в том числе и М.Ю. Лермонтов [2, с. 14]. Здесь он принимал целебные ванны, здесь же побывал в день роковой дуэли. Неслучайно, появилась и его карандашная зарисовка «Бештау близ Железноводска» (1837) [2, с. 14] (илл. 11).

На рисунке М.Ю. Лермонтова изображены два конных офрицера, скачущие вдоль улицы в сторону Бештау. В разработке пространственных планов, в серебристой дымке, покрывающей вершины гор и переданной легкой карандашной штриховкой, - во всем этом чувствуется своеобразный почерк художника. Далеко не все наброски этого периода отмечены безмятежностью. Тревожное настроение передано в рисунке «Тамань» (1837) [2, с. 14] (илл. 12).

Историю его создания описал в своих воспоминаниях российский художник М.И. Цейдлер (1816-1892). Следуя тем же почтовым трактом, что и М.Ю. Лермонтов, он видел маленький домик и его обитателей, а девушкой, редкой красоты, не на шутку увлекся. Беленая мазанка над крутым обрывом, парусник и лодки на море, очертания гор на горизонте - все это в рисунке поэта перекликается с текстом повести М.Ю. Лермонтова. Разница лишь в том, что рисунок сделан при дневном свете. В «Тамани» же мы встречаем ночной пейзаж [2, с. 15]. Направляясь к месту ссылки, в Нижегородский драгунский полк, М.Ю. Лермонтов пересек весь Кавказ. Пейзажные зарисовки, которые он делал по пути, составили целую серию. Одним из них был вид на Дарьяльское ущелье (1837). Этих знаменитых «врат Кавказа» не миновал никто из людей, следовавших по Военно-Грузинской дороге [2, с. 15]. На рисунке изображены две высокие отвесные скалы, нависшие над ущельем, по которому извилистой лентой течет Терек. В «Демоне» (1838) мы находим близкое описание этого места [2, с. 15]. Вновь М.Ю. Лермонтов использует характерный для академического пейзажа прием «кулис», обрамляющих общий вид: по дороге, вдоль русла реки, медленно движется арба, которую тянет пара волов [2, с. 15]. Совсем иной Терек, бурный и пенистый, изображен поэтом в рисунке «Дарьял» (1837) [2, с. 15] (илл. 13).

Здесь дается вид на то же ущелье, но, с другой стороны. Стиснутый отвесными скалами поток, через который перекинут шаткий мостик, извилистая тропа с гор и высоко, на вершине неприступного утеса, замок царицы. Аналогию данного 
описания мы найдем в стихотворении «Тамара» (1841) [2, с. 16]. Не менее величественный горный пейзаж - это «Вид Крестовой горы» (1837-1838) [2, с. 16] (илл. 14).

Снежная вершина, увенчанная поклонным крестом, поднимается над глубоким мрачным ущельем, по дну, которого, между отвесных скал, стремительно несется бурный поток. У подножия горы, по узкой тропе, идущей по краю пропасти, едет кибитка, запряженная парой лошадей. Белоснежные вершины и ясное небо, коричневато-серые отроги скал, пенистый водный поток - все это пронизано тонкими цветовыми редрлексами, окутано световоздушной дымкой, которая передает ощущение необъятного пространства. И вновь невольно здесь напрашивается сравнение с текстом М.Ю. Лермонтова, но теперь уже «Бэлы», которая к 1839 году была опубликована [2, с. 16]. «Вид Крестовой горы из ущелья близ Коби» (1837-1838) - так М.Ю. Лермонтов подписал автолитографию, которую сделал со второй картины, вернувшись в Петербург [2, с. 16] (илл. 15).

На крутом утесе, отроги которого почти отвесно спускаются к Тереку, возвышаются древняя башня, храм Сиони и стоит небольшое селение. Старые сторожевые башни в неприступных горах Грузии издавна служили людям, предупреждали их об опасности. Они ставились на самых высоких местах: при появлении врагов зажигали сигнальные огни, которые были видны издалека. От башни к башне, от селения к селению шла тревожная весть, передаваемая "огненной эстафретой» [2, с. 16]. В поэме «Демон» мы можем встретить подобные башни замков на скалах [2, с. 16]. Долго этого места найти не удавалось, пока не выяснилось, что это не Крестовая гора, а гора Кабарджина, вопреки мнению М.Ю. Лермонтова, который считал, что перед ним обратный склон Крестовой (близ селения Оби). Вдобавок ко всему изображение было перевернуто. Приехав в Петербург, М.Ю. Лермонтов сам перевел свою зарисовку на литографский камень, забыв, что при этом изображение следует перевернуть. Поэтому перевернутым получилось изображение на литографрском оттиске. Пришлось немало поездить вокруг селения Сиони, покуда не пришла догадка - поглядеть на литографию в зеркало. И сразу зарисованное место нашлось [2, с. 17]. Два таких оттиска раскрашены акварелью: очевидно, поэт дарил их друзьям и близким. Башня, которая показана на автолитографии, есть и на другой картине М.Ю. Лермонтова, она носит название "Кавказский вид возле селения Сиони» (1837-1838) [2, с. 17] (илл. 16).

Каменистые отроги, на которые падает последний луч заходящего солнца, нагромождение мрачных, с зеленоватым оттенком, скал, снежные вершины на горизонте и серебристо-серая туча, словно отдыхающая в глубокой расщелине утеca, - все это создает подлинно романтический пейзаж. Можно провести явную параллель между изображенным на картине и в стихотворных строчках «Утеса» (1841) [2, с. 17]. Яркие впечатления от живописных пейзажей Кавказа, поэтические легенды, непосредственно связанные с местами, которые посещал М.Ю. Лермонтов, отразились в его живописном и литературном творчестве.

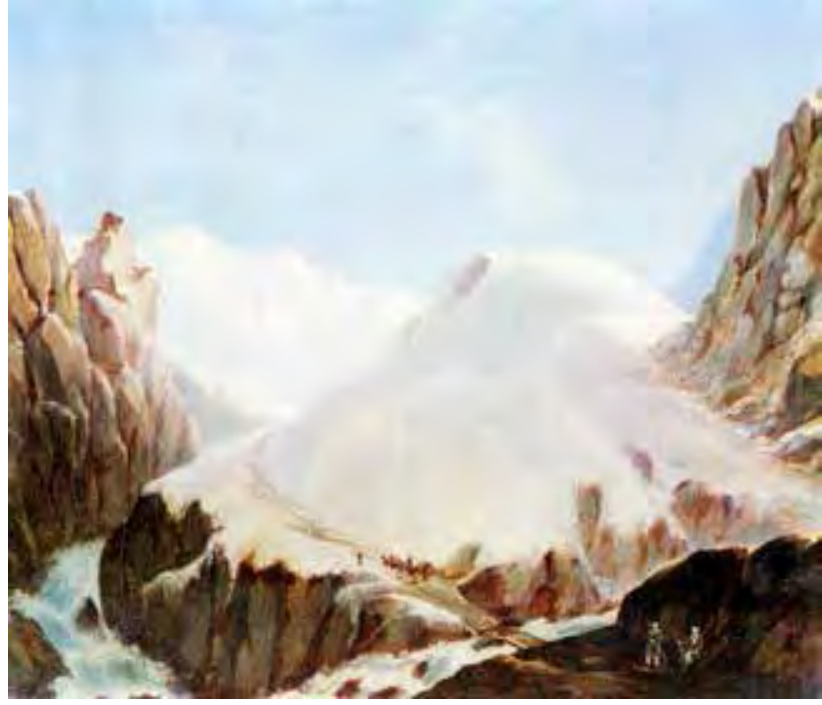

Илл. 14. М.Ю. Лермонтов. «Вид Крестовой горы». 1837-1838 гг. Картон, масло, $33,0 \times 40,00$ см //

Государственный музей-заповедник им. М.Ю. Лермонтова (Пятигорск)

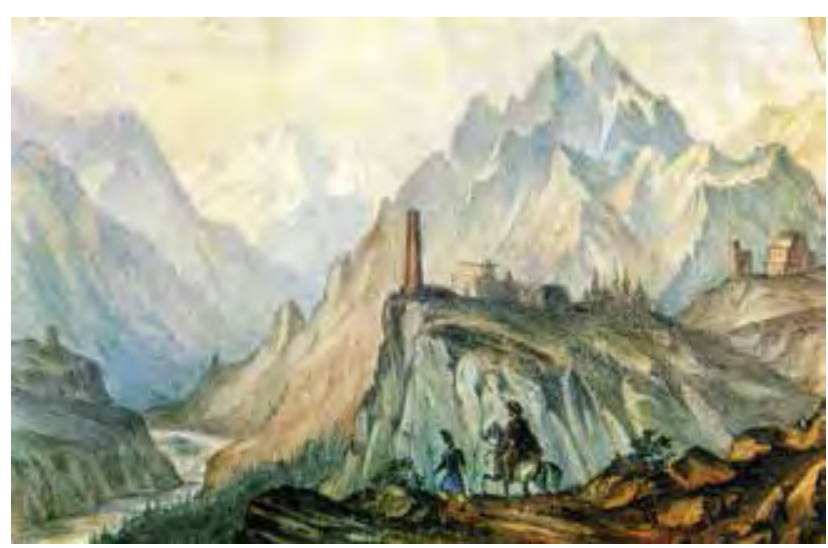

Илл. 15. М.Ю. Лермонтов. «Вид Крестовой горы из ущелья близ Коби". 1837-1838 гг. Бумага, автолитография, акварель, 15,2 $\times 22,3 \mathrm{~cm} / /$ Пушкинский дом (ИРЛИ РАН, Санкт-Петербург)

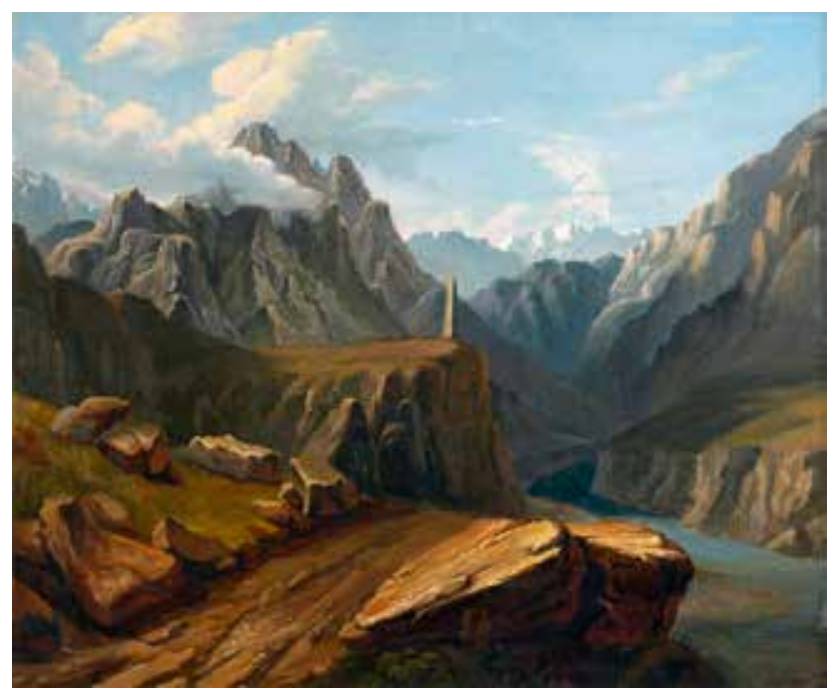

Илл. 16. М.Ю. Лермонтов. «Кавказский вид возле селения Сиони». 1837-1838 гг. Х., м., $64,0 \times 79,0$ см // Государственный

Лермонтовский музей-заповедник «Тарханы» 
Один из примеров - это «Кавказский вид с саклей (Военно-Грузинская дорога близ Мцхеты)» (1837-1838) [2, с. 18] (илл. 17).

М.Ю. Лермонтов сумел здесь передать глубокую пространственную перспективу горной гряды, уходящей к горизонту и замыкающейся вершиной Казбека. Многоплановость композиции усиливается разнообразием цветового решения: темно-зеленый кустарник сменяется желтовато-коричневым каменистым плато, над которым поднимаются поросшие лесом склоны. Золотистые лучи заходящего солнца освещают стены башни и древнего храма, а сиреневая дымка окутывает далекие горы. Подобный пейзаж мы можем увидеть в поэме «Демон» [2, с. 19]. Порой поэт вносит в пейзаж элемент бытового жанра, и тогда тот воспринимается, как сюжетная композиция, повествующая о тревожных буднях кавказцев. Такова его картина «Сцена из кавказской жизни» (Нападение)» (1838) [2, с. 20] (илл. 18).

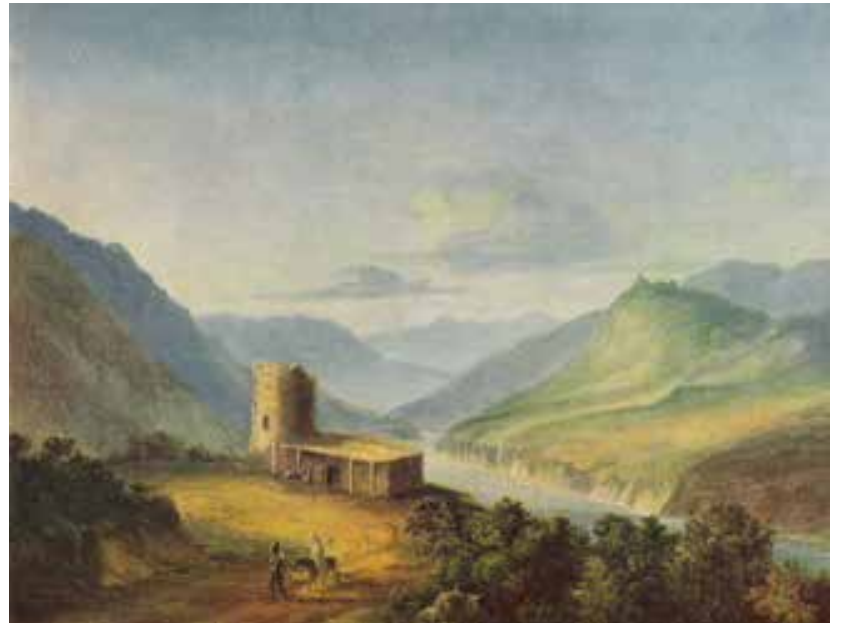

Илл. 17. М.Ю. Лермонтов. «Кавказский вид с саклей (Военно-Грузинская дорога близ Мцхеты)». 1837-1838 гг. Картон, масло, 36,0 × 43,5 см // Пушкинский дом (Литературный музей ИРЛИ РАН, Санкт-Петербург)

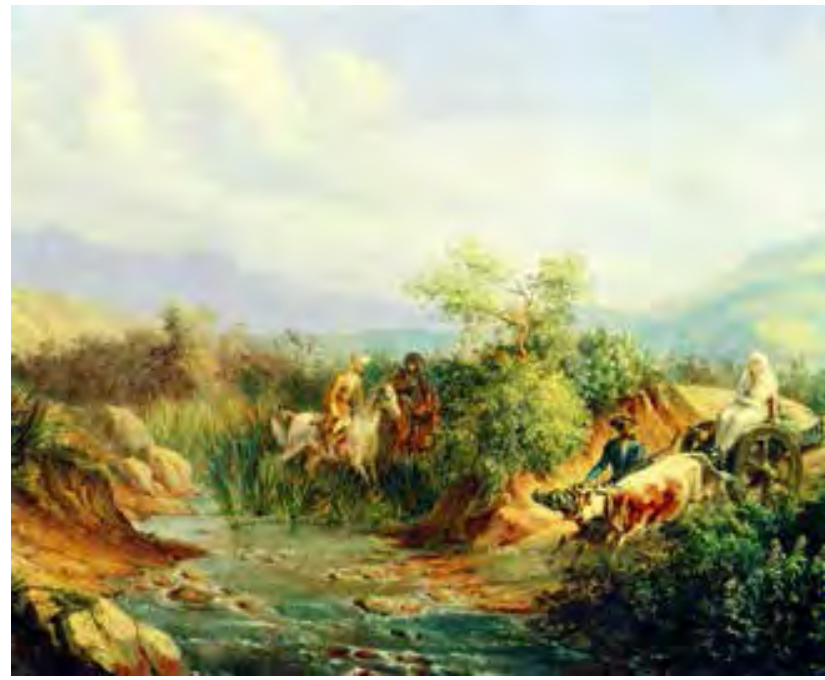

Илл. 18. М.Ю. Лермонтов. «Сцена из кавказской жизни (Нападение)». 1838 г. Дерево, масло, $39,5 \times 48,8$ см // Государственный Литературный музей (Москва)
Это уже не горный пейзаж, а долина, которыми богата Кахетия. Проезжая дорога петляет между песчаными склонами, поросшими густым кустарником. В его зарослях притаились два конных чеченца, вооруженных ружьями. Не замечая их, по дороге, спускаясь к мелководной речке, движется арба, запряженная волами. Возница, поглощенный беседой с молодой грузинкой, не замечает опасности. Несмотря на то, что картина не подписана, все выдает живописную манеру поэта. Передача световоздушной среды, голубоватые горы на горизонте, серебристые облака, окутавшие их вершины, вода в реке, деревья и кустарник - во всем этом видна манера М.Ю. Лермонтова. Жанровая сцена включена и в другой пейзаж, который называется «Кавказский вид с верблюдами» (1837-1838) [2, с. 20] (илл. 19).

М.Ю. Лермонтов изображает, нагруженных товаром верблюдов, которые медленно идут вдоль каменистой дороги. Их сопровождают горцы в высоких папахах, чохах и бурках. При взгляде на пейзаж мы вспоминаем строки из "Демона", в которых дается описание каравана жениха Тамары [2, с. 20]. М.Ю. Лермонтов посещал Тифрлис в октябре-декабре 1837 года. Он жил в доме родственника Е.Ф. Ахвердова на Садовой улице, но часто навещал знакомых в офрицерских казармах и на частных квартирах, которые находились в предместье Тифрлиса - Авлабаре, расположенном на высоком берегу Куры. Поэта впечатлила, открывшаяся оттуда панорама города, которую он изобразил в картине «Тифрлис» (1837), соотносящуюся с описанием, данным в стихотворении М.Ю. Лермонтова «Свидание» (1841) [2, с. 21] (илл. 20).

Простотой и жизненной правдой проникнута зарисовка поэтом грузинского танца - это «Грузинки на крыше сакли (Лезгинка)» (1837) [2, с. 21] (илл. 21).

Не только один поэт был пленен этой идиллической картиной, столь характерной для

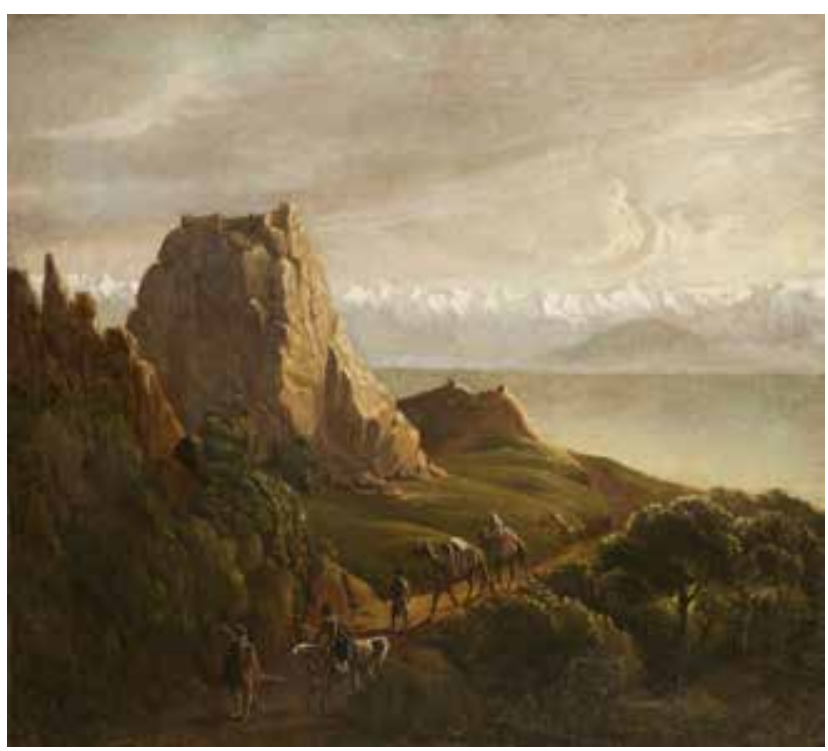

Илл. 19. М.Ю. Лермонтов. «Кавказский вид с верблюдами". 1837-1838 гг. Х., м., 62,0 × 71,0 см // Пушкинский дом (Литературный музей ИРЛИ РАН, Санкт-Петербург) 


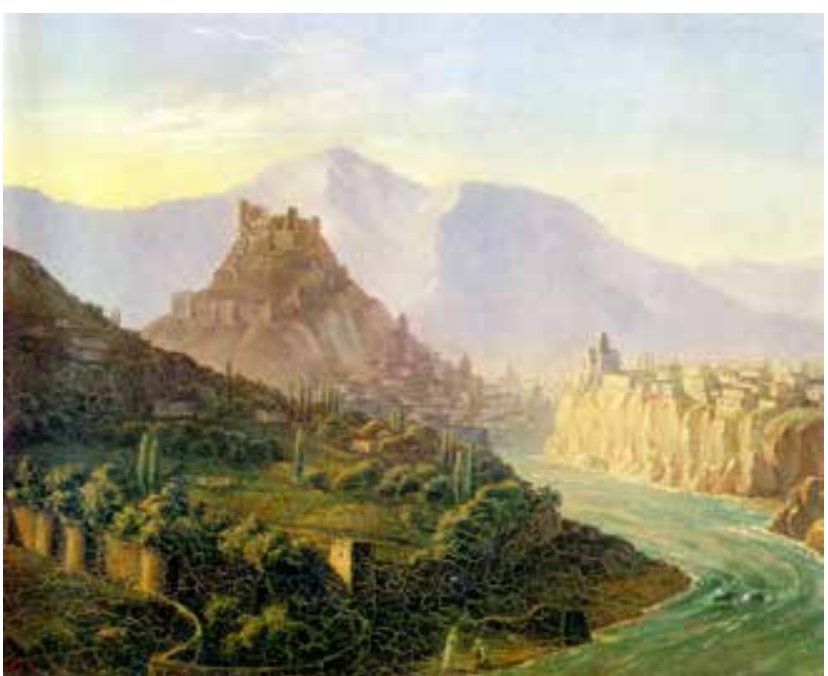

Илл. 20. М.Ю. Лермонтов. «Тифлис». 1837 г. Картон, масло, 32,2 × 39,5 см // Государственный Литературный музей (Москва)

вечернего Тифрлиса. Известны также акварели Г.Г. Гагарина, неоднократно изображавшего танец на крышах. И вновь здесь возникают знакомые строки М.Ю. Лермонтова из поэмы «Демон» [2, с. 21]. К рассматриваемому периоду относится и акварельный автопортрет поэта 1837-1838 годов, где он изобразил себя на фоне Кавказских гор в мундире Нижегородского драгунского полка: с красным воротником, в короткой бурке и газырями (патронами) на груди (илл. 22).

Дополняет экзотический костюм черкесская шашка на кабардинском ремне. Овальная фрорма произведения, манера накладывать кистью небольшие мазки, сама техника - все это тяготеет к традиции русского акварельного портрета 1830-х годов. Этот автопортрет, пожалуй, одно из лучших изображений М.Ю. Лермонтова. В нем приоткрывается "душа" поэта: недаром он подарил его Вареньке Лопухиной (Бахметьевой), глубокое чувство к которой пронес через всю жизнь [2, c. 22$]$.

Таким образом, ценность живописных полотен и рисунков М.Ю. Лермонтова заключается не только в их «документальности» [2, с. 19]. Стремление к точности воспроизведения пейзажа не заслоняет в них образное начало. Это отнюдь не бесстрастная топографическая фоиксация той или иной местности, а подлинно исторические пейзажи. В них отразилась и история Грузии, и культура страны, и редкой красоты природа, и самобытность народов. Работы поэта отличает та достоверность и непосредственность в пере-

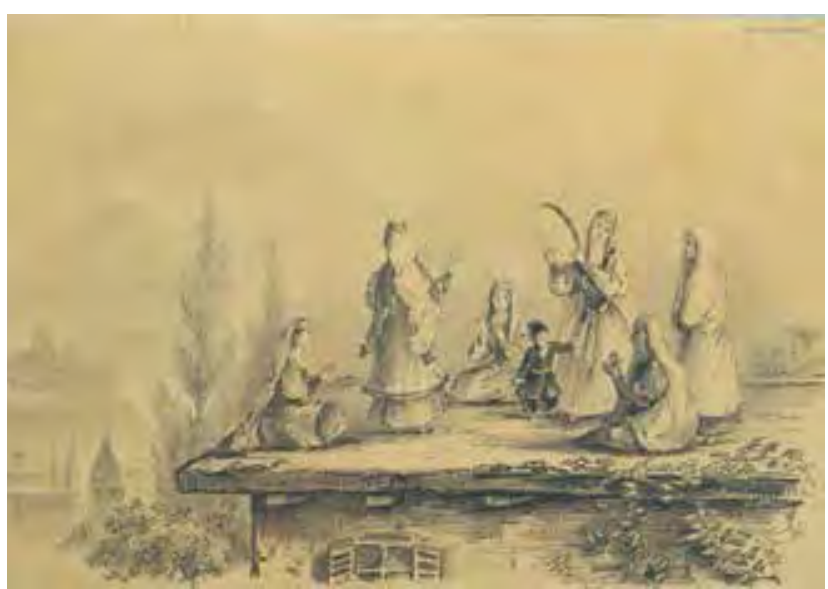

Илл. 21. М.Ю. Лермонтов. «Грузинки на крыше сакли (Лезгинка)». 1837 г. (?). Бумага, графитный карандаш, 21,5 × 31,5 см // Пушкинский дом (Литературный музей ИРЛИ РАН, Санкт-Петербург)

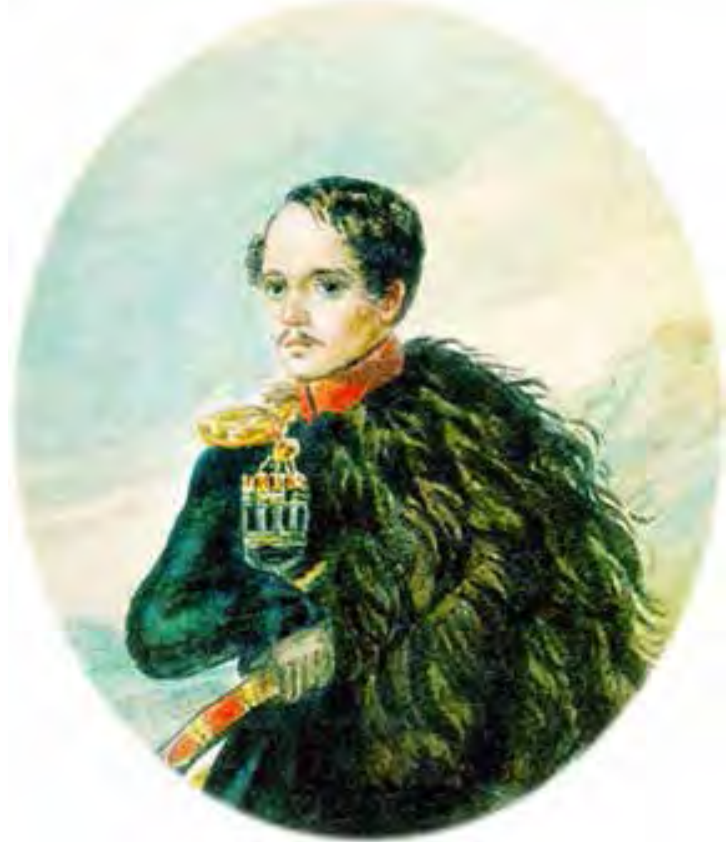

Илл. 22. М.Ю. Лермонтов. «Автопортрет». 1837-1838 гг. Бумага, акварель, белила, лак, 10,2 × 9,4 см (овал) // Государственный Литературный музей (Москва)

даче окружающего мира, которые свойственны лишь творческому человеку. Позднее русский художник Н.К. Рерих скажет о таких местах: «Везде что-то было» [2, с. 20]. М.Ю. Лермонтов умел передать это ощущение и в живописных, и в литературных произведениях.

\section{Список литературы:}

1. Живописное наследство Лермонтова. Исследование Н. Пахомова. Лермонтов-художник / Литературное наследство. Т. 45-46. Кн. ІІ. М.Ю. Лермонтов. Москва : Изд-во АН СССР, 1948. С. 55-222.

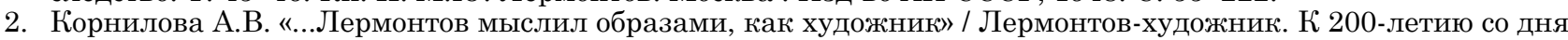
рождения М.Ю. Лермонтова. 2-е изд. испр. и доп. Государственный Лермонтовский музей-заповедник «Тарханы», 2015. С. 7-29.

3. Лермонтов. Картины. Акварели. Рисунки / Вступит. ст. И.Л. Андроникова. Москва : Изд-во: «Изобразительное искусство», 1980.247 с.

4. Михаил Юрьевич Лермонтов. Картины и рисунки поэта. Иллюстрации к его произведениям / Сост. и авт. вступит. ст. Е.А. Ковалевская. М.-Л. : Изд-во: «Советский художник», 1964. 127 с. 
5. Полное собрание сочинений М.Ю. Лермонтова: в 5 томах / под ред. и с примеч. Д.И. Абрамовича. СПб.: «Разряд изящной словесности Имп. Акад. наук», 1910-1913 (Академическая библиотека русских писателей. Вып. 2-6). Т. 5: Произведения, не вошедшие в предыдущие тома ; Библиография ; Вводные объяснительные статьи. 1913.

\section{References:}

1. Zhivopisnoe nasledstvo Lermontova. Issledovanie N. Pahomova. Lermontov-hudozhnik / Literaturnoe nasledstvo. T. 45-46. Kn. II. M.Ju. Lermontov. Moskva : Izd-vo AN SSSR, 1948. S. 55-222.

2. Kornilova A.V. "...Lermontov myslil obrazami, kak hudozhnik» // Lermontov-hudozhnik. K 200-letiju so dnja rozhdenija M.Ju. Lermontova. 2-e izd. ispr. i dop. Gosudarstvennyj Lermontovskij muzej-zapovednik «Tarhany», 2015. S. 7-29.

3. Lermontov. Kartiny. Akvareli. Risunki / Vstupit. st. I.L. Andronikova. Moskva : Izd-vo: «Izobrazitel'noe iskusstvo», 1980. $247 \mathrm{~s}$.

4. Mihail Jur'evich Lermontov. Kartiny i risunki po`eta. Illjustratsii k ego proizvedenijam / Sost. i avt. vstupit. st. E.A. Kovalevskaja. M.-L. : Izd-vo: «Sovetskij hudozhnik», 1964. 127 s.

5. Polnoe sobranie sochinenij M.Ju. Lermontova: v 5 tomah / pod red. i s primech. D.I. Abramovicha. SPb.: «Razrjad izjaschnoj slovesnosti Imp. Akad. nauk», 1910-1913 (Akademicheskaja biblioteka russkih pisatelej. Vyp. 2-6). T. 5: Proizvedenija, ne voshedshie v predyduschie toma; Bibliografija; Vvodnye ob"jasnitel'nye stat'i. 1913. 